\title{
MULTILINGUA - Introduction and editorial programme
}

\author{
J. C. SAGER \\ Editor
}

\section{Kurzfassung}

Der während der 70er Jahre erzielte Fortschritt im Bereich der einsprachigen WTID führte zu Verbesserungen im Informationstransfer zwischen Sprachen. Während die diesem Fortschritt zugrunde liegenden Bereiche der Telematik und Informatik in verschiedenen Veröffentlichungen ausführlich behandelt werden, kam der Kommunikation zwischen natürlichen Sprachen bisher nicht die Beachtung zu, die sie verdient, und gerade diese Lücke soll MULTILINGUA füllen, indem die Zeitschrift unsere mehrsprachige Gesellschaft und die ganze Tragweite dieser Tatsache stärker ins Bewusstsein rückt.

Die zunehmende internationale Zusammenarbeit führte dazu, dass man sich der Sprachbarrieren stärker bewusst wurde, insbesondere in der Europäischen Gemeinschaft, deren Erfolg weitgehend von der Fähigkeit ihrer

Mitgliedstaaten abhängt, leicht miteinander zu kommunizieren.

Die Schirmherrschaft, die die

Kommission der Europäischen

Gemeinschaften dieser

Zeitschrift zukommen lässt, ist

nur ein Aspekt ihres

Aktionsplans für

Mehrsprachigkeit, der der

grösste jemals den Fragen der

Mehrsprachigkeit gewidmete

F \& E-Haushalt ist.

Die Kommission ist einer mehrsprachigen Gesellschaft verpflichtet. Die

Redaktionspolitik von

MULTILINGUA beruht daher

auf dem Bewusstsein, dass

sprachliche Vielfalt kulturelle

Bereicherung bedeutet, dass in

bestimmtem Ausmass

Verbesserungen im

herkömmlichen

zwischensprachlichen Kontakt möglich sind, dass die Entwicklungen in der Informationstechnologie und Linguistik sowie der voll oder halbautomatisierte

Informationstransfer zwischen Sprachen neue Möglichkeiten bieten.

MULTILINGUA richtet sich an alle diejenigen, die Einfluss auf Sprachpolitik haben oder an ihrer Ausführung mitwirken: an Sprachmittler, Forscher für zwischensprachlichen Transfer, Verteiler mehrsprachiger Information und an alle, die an den Werten und Folgen der Mehrsprachigkeit interessiert sind. Die Zeitschrift möchte nicht nur ein Forum bieten, sondern auch Informationen zusammenbringen, die gegenwärtig weit verstreut sind, und über Innovationen in Linguistik, Informatik und Telematik berichten, da diese Auswirkungen auf die zwischensprachliche

Vermittlung haben.

Schwerpunktbereiche werden mehrsprachige Planung auf allen Stufen, Sprachunterricht und Sprachenlernen sowie Theorie und Praxis des Uebersetzens und Dolmetchens sein.

Die Zeitschrift wird im wesentlichen Kurzreferate, aber auch Buchbesprechungen und Informationen über

Veranstaltungen enthalten. Die ersten Nummern werden eher retrospektiv sein und über den derzeitigen Stand in diesem

Bereich berichten, in späteren wird das Verhältnis zwischen neuen Ideen und Vorhandenem besser ausgewogen sein. Die

Beiträge erscheinen in allen Gemeinschaftssprachen mit Kurzfassungen auf Englisch, Französisch, Deutsch und Italienisch.

Der Redaktionsausschuss ist sich dessen bewusst, dass er eine sehr schwere Aufgabe
In all areas of communication the 1970 s were a time of rapid change and development. Progress was most notable in (monolingual) scientific and technological information and documentation, but this largely computer-based innovation also influenced other forms of communication and is currently being exploited for improving the transfer of information between languages.

These achievements are the result of interdisciplinary studies and applications combining telecommunications, electronics, computer and information science and more recently linguistic and cognitive studies, which have been grouped under the broad labels of telematics and informatics, subject headings which yet require full definition and delimitation against each other and against related disciplines. These activities are also reflected in numerous publications and especially journals, reviews and newsletters seeking to coordinate and stimulate research and new applications. The substance of communication, natural language, and especially the problems of communication between natural languages have, however, not yet been given the full attention they deserve and no regular publication is primarily devoted to them. MULTILINGUA is intended to fill this gap and to create a wider awareness of the implications of a multilingual society.

Growing international cooperation has stimulated all these developments toward overcoming the barriers of distance, economic inequality and even political ideology, but in this process the barriers of languages have come to be felt even more severely and further progress in this direction will largely depend on finding solutions to the obstacle that is the diversity of natural languages. The need for assistance in interlingual communication is felt acutely in the European Community whose success in forging closer economic, political and cultural links among its member states largely depends on their ability to communicate with each other with the same ease as inside their own countries. It is, therefore, not surprising that the various European Institutions together should have set up the largest and most complex translation and interpreting services ever assembled and that they should 
have devoted particular attention to these problems. The sponsorship which the Commission of the European Communities affords this journal is only one in a long list of actions initiated since 1977, under the title of Multilingual Action Plan, which together represent the largest single research and development budget ever devoted to multilingual problems.

MULTILINGUA appears at a time and within an environment of considerable technological innovation and interest in interlingual communication. It is supported by an institution whose guiding principles, emanating from the Treaty of Rome, express a commitment to a multilingual society. It recognizes the cultural diversity represented by different languages and rejects the simplistic solutions variously sought in the proposals for artificial languages or the adoption of universal linguas francas.

The editorial policy of MULTILINGUA is therefore based on the recognition that

- linguistic diversity is a positive value which enriches our world and contributes to its full cultural and intellectual development;

- communication between different linguistic communities can be assisted and facilitated by improving the conventional means available for interlingual contact, viz. language learning, translating and interpreting;

- information technology and linguistics have reached a state of progress which permits the development of improved techniques and tools for this purpose;

- automated and semi-automated processes of information transfer between languages can be developed to widen the scope of interlingual communication.

The journal addresses itself to -

- all those who are influential in determining and carrying out appropriate language policies;

- the many professionals directly involved or assisting in linguistic mediation, i.e. translators, interpreters, language teachers, information scientists, lexicographers, terminologists, technical writers;

- researchers and developers in the many fields which can make contributions to improving and facilitating information transfer between languages;

- distributors of multilingual information, such as publishers, librarians, data base and network managers; - those generally interested in the practical values and effects of multilingualism.

For this body of potential readers and contributors the editorial board wants to provide a forum for discussion and for the exchange of information on relevant language policies, fundamental research into the processes of interlingual information transfer and developments in achieving more effective interlingual communication. It übernommen hat, glaubt jedoch, dass ein engerer Kontakt zwischen Theorie und Praxis in der

zwischensprachlichen

Kommunikation eine

wesentliche Voraussetzung für

Fortschritte in diesem wichtigen

Bereich ist. Für die erste Zeit

bittet er die Leser um

Nachsicht, bis bei Inhalt und

Ton das richtige Mass

gefunden ist, er bittet um ihre

Mitwirkung, damit

MULTILINGUA zum führenden

Organ für zwischensprachliche

Kommunikation wird.

\section{Abstract}

The progress made during the 70 s in monolingual IDST has led to improvements in the transfer of information between languages. While the underlying fields of telematics and informatics are well covered in various publications, communication between natural languages has not yet received the attention it deserves, and it is this gap which MULTILINGUA is intended to fill, by creating a wider awareness of the implications of a multilingual society.

The growth of international co-operation has led to a greater awareness of the barriers of language, in particular in the European Community, whose success depends largely on the ability of its Member States to communicate easily with each other. The sponsorship which the Commission of the

European Communities affords this journal is only one aspect of its Multilingual Action Plan, which represents the largest $R$ and $D$ budget ever devoted to multilingual problems.

The Commission is committed to a multilingual society. The editorial policy of MULTILINGUA is based therefore on an awareness of the cultural enrichment offered by linguistic diversity; of the scope for improvements in conventional interlingual contact; of the possibilities offered by developments in information technology and linguistics; and of the potential of fully or semi-automated information transfer between languages.

MULTILINGUA addresses itself to all who influence or execute language policy: to professionals in linguistic mediation; to researchers in interlingual transfer; to distributors of multilingual information; and to all those interested in the values and effects of multilingualism. It aims not only to provide a forum but also to bring together information which is at present widely dispersed, and to report on innovations in linguistics, informatics and telematics as they affect interlingual mediation.

Particular areas of interest will be multilingual planning at all levels; language teaching and learning; and the theory and practice of interpreting and translating.

The journal will provide a substantial abstracting service, as well as book reviews and information on events. The initial issues will tend to be retrospective, to survey the state of the art, later ones will be more balanced between new ideas and existing work.

Contributions will be in any of the Community languages, with abstracts in English, French, German and Italian.

The editorial board is aware of the complexity of the task it has taken on, but believes that closer contact between theory and practice in interlingual communication is essential for progress in this important area. It asks readers' indulgence in the early stages, until the right balance of content and tone has been established, and invites their participation in establishing MULTILINGUA as the leading voice on interlingual communication.

\section{Résumé}

Les progrès réalisés en IDST unilingue au cours des années 1970 ont permis d'améliorer le transfert de l'information entre les langues. Si les domaines fondamentaux de la télématique et de l'informatique sont largement traités dans diverses publications, la cornmunication entre les langages naturels n'a pas encore reçu l'attention 
will bring together information on interlingual communication which is at present widely dispersed and hopefully stimulate the expression of opinion and research in this arca which has hitherto not found a suitable medium of publication.

As interlingual communication pervades many existing fields of study. some with their own publications, it is convenient to distinguish and define the core areas which the editorial board considers to be of primary interest. Many of these overlap, especially in practical applications, and most are supported by computer technology.

Bilingual and multilingual language planning at institutional, national and supranational levels are of particular importance. This field, normally considered an aspect of sociolinguistics, is fundamental to interlingual communication as the will to make provision for variety of expression in languages is a precondition for the successful implementation of plurilingual language policies. The experience of bilingual countries, the status and practice of official and working languages and the daily experience of both participants and mediators in interlingual communication are a valuable guide to the research and development of new tools and techniques.

Equally fundamental is the practice of language teaching and learning both for direct participation in interlingual contact and for professional mediation. There are a number of journals mainly devoted to this aspect of applied linguistics. MULTILINGUA proposes only to cover highly specific forms of teaching and learning and to give particular attention to the training of professional mediators.

The theory and practice of interpreting and translating will occupy a major place in the journal. Whilst many translators' associations have their own publications, there are few, if any, which survey all forms of linguistic mediation and directly place them in the wider context of modern information technology. MULTILINGUA will therefore not be a competitor but a useful complement to existing periodicals in this field.

The main thrust of this journal is seen to lie in presenting and reporting on innovatory research and development in linguistics, informatics and telematics supporting or complementing existing forms of interlingual mediation. Recent progress in word- and textprocessing, automated dictionaries, machine translation, data base technology, information systems and networking offer new prospects for wide-ranging, cost-effective and efficient interlingual communication.

In its Action Plan the Commission of the European Communities has sponsored a number of projects in this area, the results of which have not yet been made public, and numerous other research and development activities qu'elle mérite et c'est cette lacune que MULTILINGUA se propose de combler en faisant prendre plus largement conscience des implications du multilinguisme.

Le développement de la cooperation internationale a mis en lumière les problèmes posés par les barrières linguistiques, notamment au sein de la Communauté européenne dont le succès dépend largement de la capacité des Etats Membres de communiquer facilement entre eux. Le patronnage que la Commission des Communautés Européennes accorde à ce bulletin d'information n'est qu'un des aspects de son Plan d'Action multilingue qui représente le plus important budget de recherche et de développement jamais consacré aux problèmes multilingues.

La Commission ne peut échapper au multilinguisme. C'est pourquoi, le comité de rédaction de MULTILINGUA a choisi de mettre l'accent sur l'enrichissement culturel que constitue la diversité linguistique, sur les possibilités d'amélioration des contacts interlingues traditionnels, sur les possibilités offertes par les progrès réalisés en matière de technologie de l'information et de linguistique et sur le potentiel que représente le transfert automatisé ou semiautomatisé de l'information entre les langues.

MULTILINGUA s'adresse à tous ceux qui ont une influence sur les orientations linguistiques ou les mettent en oeuvre; aux professionnels de la médiation linguistique, aux chercheurs dans le domaine du transfert interlingue, à ceux chargés de diffuser des informations. multilingues et à tous ceux que les valeurs et les effets du multilinguisme intéressent. Son but $n$ 'est pas uniquement de servir de tribune, mais également de rassembler des informations à présent dispersées aux quatre vents et de rendre compte des innovations dans les domaines de la linguistique, de l'informatique et de la télématique dans la mesure où elles influencent sur la médiation interlingue. Ses centres d'intérêt seront notamment la concertation multilingue a tous les niveaux. l'enseignement et l'apprentissage des langues, et la theorie et la pratique de l'interprétation et de la traduction.

Le bulletin offrira un important service d'analyses, ainsi qu'une critique des ouvrages publiés, et des informations sur l'actualité. Les premiers numéros seront plutốt rétrospectifs et essayeront de faire le point de la situation du multilinguisme: les ruméros suivants seront mieux partagés entre idées nouvelles et travaux en cours. Les articles seront publiés dans l'une des langues communautaires avec résumés en anglais, français, allemand et italien.

Le bureau de rédaction est conscient de la complexité de la tâche qu'il a entreprise mais i) estime qu'une relation plus étroite entre la théorie et la pratique dans la communication interlingue est indispensable pour que des progrès soient réalisés dans ce secteur important. II demande aux lecteurs de faire preuve d'indulgence en cette période de balbutiements jusqu'à ce que la revue ait trouvé le juste équilibre entre le fond et la forme et de l'aider à faire de MULTILINGUA le premier organe de la communication interlingue.

\section{Compendio}

I progressi compiuti nell'IDST monolingue negli anni ' 70 hanno portato a miglioramenti negli scambi di informazioni tra le lingue. Mentre i settori fondamentali della telematica $e$ dell'informatica vengono ampiamente trattati in varie pubblicazioni, la comunicazione nelle lingue naturali non riceve ancora tutta l'attenzione che merita, e MULTILINGUA ha lo scopo di colmare questa lacuna, creando una maggiore coscienza delle implicazioni di una società multilingue.

Una cooperazione internazionale più ampia ha portato alla consapevolezza. delle barriere linguistiche particolarmente nella Comunità Europea, il cui successo dipende in gran parte dalle possibilità di una più facile 
are largely unreported or dispersed (in other publications) and therefore not fully exploited. MULTILINGUA proposes to report on current research and to publish summaries and critical evaluations of projects in the hope of offering assistance in the coordination of this work. Automation of dictionary production and consultation, for instance, have led to a totally new concept of the dictionary user as creator of, or contributor to dictionaries. The management of automated dictionaries, at the same time, benefits from progress in data base management techniques evolved for information systems and can simultaneously provide models for the dictionaries needed for machine translation.

On-line searching of remote multilingual data bases is now a technical reality but the diversity of accessing tools, command languages and search strategies itself represents a multilingual problem quite independent of the diverse natural languages of the stored information and those the searcher has a command of. Translation systems are therefore required at two hierarchical levels, between the natural languages and between the information languages created on the basis of natural languages.

Specialized lexicography, terminology, information storage and retrieval, and machine translation are therefore not seen as isolated areas of study and application but as mutually complementary activities under such headings as computational linguistics, information systems and management.

In order to give readers an overview of the research with multilingual dimensions or implications a substantial service of abstracts will be provided in each issue beside the customary book reviews, announcements of events and reports of conferences.

The publishers and the editorial board are aware of the difficulty of their task of presenting such a wide range of highly complex topics to a seemingly heterogeneous readership. Nevertheless, they believe that closer contact between theory and practice, research and application across the whole spectrum of activities associated with interlingual communication, information and documentation is essential for progress in this important area of human enterprise. This task should therefore also become progressively easier as greater concern and understanding become more widespread.

The first few issues will have a retrospective orientation in order to survey the present state of the art. Later issues will then have a more even balance between new ideas and reports of existing work.

In order to assist them in the selection and assessment of contributions the members of the editorial board comunicazione tra gli Stati Membri. II patrocinio offerto dalla Commissione delle Comunità Europee a questa pubblicazione costituisce soltanto un aspetto del suo Piano d'Azione Multilingue, che rappresenta il maggiore stanziamento Ricerca e Sviluppo accordato mai a problemi di multilinguismo.

La Commissione è impegnata in una società multilingue, quindi la politica editoriale di MULTILINGUA è basata sulla consapevolezza :-

dell'arricchimento culturale offerto dalle differenze linguistiche, dall'opportunità di miglioramenti negli scambi interlinguistici convenzionali, delle possibilità offerte dagli sviluppi della tecnologia, dell' informazione e della linguistica e del potenziale costituito dal trasferimento di informazioni tra le lingue parzialmente o totalmente automatizzato.

MULTILINGUA si rivolge a tutti coloro che influenzano o intervengono nellá politica linguistica; ai professionisti della comunicazione tra le lingue; ai ricercatori nel campo degli scambi interlinguistici; a chi distribuisce informazioni multilingui; e a tutti quelli che si interessano ai valori ed agli effetti del plurilinguismo. MULTILINGUA si propone non solo di costituire una tribuna ma anche di riunire informazioni attualmente sparse in varie pubblicazioni e di riferire sulle innovazioni linguistiche, informatiche $e$ telematiche come influenzano la comunicazione fra le lingue. Zone d'interesse particolare saranno costituite dalla pianificazione multilingue a tutti i livelli; dall'insegnamento e dall'apprendimento delle lingue e dalla teoria e dalla pratica dell'interpretazione e della traduzione.

La pubblicazione fornirà un servizio di sommari, recensioni e informazioni sugli eventi. I primi numeri avranno un carattere retrospettivo, allo scopo di fornire un quadro della situazione, quelli successivi invece costituiranno un giusto equilibrio di nuove idee e lavoro già effettuato. Gli articoli saranno redatti nelle lingue ufficiali della Comunità, con somari in inglese, francese, tedesco e italiano.

La direzione editoriale è ben conscia della complessità del lavoro intra ma che ritiene che un più stretto contatto tra teoria e pratica nelle comunicazioni interlinguistiche sia fondamentale per progredire in un campo cosi importante. Si augura quindi di incontrare l'indulgensa dei lettori nelle fasi iniziali, finchè non venga raggiunto il giusto equilibrio tra contenuto e accenti e invita questi a fornire la loro collaborazione per fare di MULTILINGUA il portavoce della comunicazione interlinguistica. 
cover a wide spectrum of topics and approaches and they will be assisted by a large circle of consulting editors whose interests and expertise should safeguard the quality and balance of the various contributions. All original contributions will be subjected to a system of double refereeing and carefully edited so as to make them accessible to the whole range of readers.

The journal will publish contributions in all European Community languages, with major emphasis on English,
French, German and Italian. Articles will be preceded by abstracts in these four languages.

Finally, the editorial board would ask readers to be indulgent in the early stages of publication until the right balance of content and tone has been established. They also invite their active participation in helping to establish the journal as the leading voice on topics of interlingual communication.

The Editor 